\title{
VALUE OF A BOND DEPARTMENT TO A BANK OR TRUST COMPANY
}

\author{
By George B. Caldwell,
}

Manager Bond Department, The American Trust and Savings Bank, Chicago.

It is within the past five years that the attention of the public has been directed to the action taken by some of our largest national banks and many of our trust companies in opening bond departments. There is little doubt but that this movement has met with popular approval by both the public and the managers of the banks that have entered this new field of banking. Prior to 1900, the handling of bonds was confined almost entirely to private banks. The progress in banking which has brought about the trust company, with its various departments, has led to the establishment of the bond department as an important part of a modern trust company.

The many millions of dollars' worth of bonds that have been put upon the market during the last few years could not have been handled had the work been undertaken by the private banks alone. The funds at their command were inadequate to carry on a business of such great magnitude, and this made it inevitable that the private banker must have the assistance of the larger banks. The banks found that the bond business was a special line of banking, differing very materially from that of discounting commercial paper, or loaning money on real estate, and that in order to aid the bond houses successfully, as well as to further the best interests of their clients, a special department in the hands of experienced men was essential. Experience has proven that this was at least a safe, profitable and dignified course for the banks to pursue. In this way the private banks have been greatly benefited. They have found a man in the bond department of their bank who could comprehend their needs and aid them in their undertakings. This I should say was the original reason that led many of the larger banks to form and maintain bond departments.

The bond department of a bank, besides being an aid to the various bond houses, has also found a large field of operation and (230) 
responsibility in the investment of a considerable portion of the bànk's own funds. There are few national banks, and a less number of trust companies, that do not invest in bonds. The percentage of increase in the assets of banking institutions of all kinds in bonds since $I 900$ is over 300 per cent. To have these investments carefully scrutinized by those familiar with the issuing of bonds is in itself of great value to the larger banks and trust companies which carry an investment of from $\$ 1,000,000$ to $\$ 50,000,000$ in bonds.

In addition it may be said that the growth of the bond business, aided by the larger banks in the country, has opened another avenue of profit, viz., that of supplying the investment demand. Among the customers of every bank are some persons with funds to invest who desire an income larger than can be secured from the rate of interest paid on savings deposits. Such customers will seek their banker for advice and ask him to recommend investments for them. The banker, desiring to be helpful to his customers, feels the additional responsibility to be somewhat greater than he is always qualified and willing to undertake, but by the aid of his organization, one branch of which is a well-organized bond department, he has a place to which all such inquiries can be referred, and through which such investments can readily be made.

Another feature of banking which has no doubt been aided to a considerable extent through the agency of the bond department is that of passing upon collateral offered the bank from time to time for loans. All banks loan the larger percentage of their money on collateral, and heretofore the banks have had only a limited knowledge of the character of this collateral, gained largely from stock exchange and curb market quotations. Beyond the investigations made by the banks themselves through their various credit departments, they are frequently aided in their judgment of both stocks and bonds by the statistics and ready information to be found in the bond department. The bond department also creates a great deal of new business for the trust department of a trust company, and frequently arranges many new loans which the banking department can take to advantage.

The bond department of a modern bank to be efficient and of value must not only be equipped with a manager, but must have on its staff competent men as appraisers, auditors and attorneys to pass judgment upon properties and to act as employees in the buying 
end of the business. Such a department must also have a sales manager and various salesmen to look after the advertising and selling and to place before the public the various bonds they desire to offer for sale. Through the agency of the buying department, all banks come into possession of detailed knowledge at the hands of their official staff, charged only with the responsibility of protecting the bank's funds. In the selling end of a bond department, the bank comes into contact with the investing public, which is not alone confined to the customers of the bank, or trust company, but to those of other banks and trust companies and other bond houses. This aids the bank in securing knowledge of the general market conditions that should be of benefit to any banking institution in making new friends and obtaining valuable information bearing upon the future welfare of the bank.

In general, it may be said that as the investment field broadens the work of the bond department will naturally grow and become of still greater importance. It will educate and turn out a large number of capable and careful men to become the future traders in securities. It is certainly wise that these men should be educated under the influence of banks where the standards of moral responsibility, as well as of financial credit and strength are high. In their education in this department, they are continually impressed with this standard. As they grow up it becomes a part of them, and in after years it will become an element of security to the investing public. Banking houses operating bond departments do not and cannot afford to offer the public at any time securities which do not possess both "security" and "income." Public insight into financial institutions and into public loans of all kinds is keen, and has been trained to discern any technicality or slight irregularity. For any banking institution to recommend any investment that will not bear the closest examination would be very detrimental to its business. The zealous maintenance of this principle will both broaden the market for bonds and bring to banks and trust companies a large and profitable business yet in its infancy. 